\title{
A CRITICAL REFLECTION ON MY READING AND RE-READING OF EMERITA QUITO'S THOUGHTS ON THE UNDERDEVELOPMENT AND HOPE FOR THE DEVELOPMENT OF FILIPINO PHILOSOPHY
}

\author{
Feorillo P.A. Demeterio III \\ Filipino Department, De La Salle University, Philippines
}

Quito published her book The State of Philosophy in the Philippines in 1983. When the book was already out for fifteen years, I undertook a re-reading of its identified four clusters of reasons for the underdevelopment of Filipino philosophy, and hope for development in 1999, through an article "Re-Reading Emerita Quito's Thoughts Concerning the Underdevelopment of Filipino Philosophy." Thirty-six years after the publication of Quito's book, and twenty years after the publication of my re-reading, this paper looks back again on Quito's four clusters of reasons and hope, as well as on my re-reading of such reasons and hope, with the intention of sharpening our collective diagnosis on what continue to cause the underdevelopment of Filipino philosophy, as well as imagining more realistic pathways towards its more robust development. This paper, therefore, has two substantive sections: the first is an exposition of Quito's four clusters of causes and hope, accompanied by my commentaries on such four causes and hope; and the second is my present critical reflection on Quito's thirty-four-year-old diagnosis and hope, as well as on my twenty-year-old commentary.

\section{INTRODUCTION}

Emerita Quito (1929-2017), one of the brightest luminaries of Filipino philosophy, made an incisive diagnosis of the causes of the underdevelopment of Filipino philosophy as well expressed her hopes for its development in her 1983 book The State of Philosophy in the Philippines. In this book, she identified a number of such causes, which we may heuristically organize into four groups and refer to as the: 1) historical problems, 2) economic and institutional problems, 3) linguistic problems, and 4) cultural problem. Her hope was for Filipino folk philosophy to offer Filipino 
academic philosophy concepts, categories and thought systems that would eventually catalyze the latter's development.

When Quito's book was already in circulation for sixteen years, I undertook a rereading of its identified four causes of the underdevelopment of Filipino philosophy as well as on her hope for development, through a 1999 article "Re-Reading Emerita Quito's Thoughts Concerning the Underdevelopment of Filipino Philosophy" (1999). That article started as a graduate studies term paper in 1994 and a paper presentation in a Filipino philosophy conference at the University of the Philippines - Diliman in 1997. Such re-reading basically re-contextualized Quito's causes and hope to the conditions and realities of Metro Manila and the Philippines in the late 1990s, as well as sharpened further her assertions. There were many things that changed in between 1983 and 1999. For example, in 1983 Andrew Gonzalez, FSC (1940-2006) a visionary in the field of Philippine higher education, was still trying to upgrade the salaries of professors at De La Salle University, eventually setting up a national benchmark on salaries of academic personnel. By 1999, there were already a number of Philippine higher educational institutions (HEIs) that provided decent salaries to its academic personnel. As another example, in 1983, the personal computer and the internet were still unknown to many people in the Philippine academe. By 1999, these things were already taken for granted.

Now, thirty-six years have passed after the publication of Quito's book, and twenty years after the publication of my re-reading. I deem it timely and necessary to revisit Quito's four cluster of causes and hope, as well as my re-reading of such causes and hope, and re-contextualize them again to the conditions and realities of contemporary Metro Manila and the Philippines. There are again many things that changed in between 1999 and 2019. For example, the country now has two research universities, the University of the Philippines System since 2008 and De La Salle University since 2011, and a number of state universities that aspire to become research universities. As another example, many Filipino academic personnel are now routinely pressured to deliver conference papers and publish journal articles and books.

More significant than these external changes, my point of view has drastically changed. In 1999 I was just an associate professor at San Beda College struggling to finish my long overdue doctoral dissertation, while in 2019 I am already a full professor at De La Salle University with decades of research projects on Filipino philosophy and a decade of experience as a college and university research manager. There are definitely things that I could not see in Quito's work in 1999 that would suddenly appear clearly to me at present. Furthermore, I had the opportunity of presenting this paper at the $6^{\text {th }}$ Thomasian Philosophers Reunion Convention in January 2020, where I gleaned valuable comments and reactions from a number of philosophy professors and students of the University of Santo Tomas.

The intention of this re-reading is to sharpen our collective diagnosis of what continue to cause the underdevelopment of Filipino philosophy, as understanding such causes will already be a giant step towards Filipino philosophy's further development; as well as to expand Quito's hope so that the development of Filipino philosophy need not run on a single difficult track but on multiple and more attainable tracks. To attain its intentions this paper, therefore, has two substantive sections: the first is an 
exposition of Quito's four cluster of causes and hope, accompanied by my 1999 commentaries on the said causes and hope; and the second is my present critical reflection on Quito's thirty-four-year-old diagnosis and prognosis, as well as on my twenty-year-old commentary.

\section{READING AND RE-READING OF QUITO}

As mentioned in the preceding section, this first substantive section would be an exposition of Quito's four clusters of causes and hope, accompanied by my 1999 commentaries on the said causes and hope. It should be noted that names of the clusters were my creations as I crafted my 1999 commentary. They may not be the perfect labels, but for the sake of consistency I opted to maintain these names in this present paper. It should be remembered also that when Quito diagnosed the problems of Filipino philosophy, she was looking at the general trend. There will always be exceptional cases that will contradict her assertions, but we should not be distracted by such non-systemic occurrences and focus instead on her intention of analyzing the big picture of the state of philosophy in the Philippines.

\section{Historical Problems}

There were two historical problems concerning the underdevelopment of Filipino philosophy that were identified by Quito in her book. The first one was the detrimental hegemony of Thomism. Quito $(1983,9)$ wrote: "the hold of the Catholic faith on the minds of the Filipino people has been so tenacious that most people no longer draw a line between religion and faith on the one hand, and philosophy and reason, on the other hand. As a result, the most prominent philosophical trend among the majority of professors until the 1960's had been Catholic philosophy, or to be more specific, the philosophy of Saint Thomas Aquinas."

In 1999, I pondered that even though there were already a number of Filipino philosophy professors who breached the cognitive prison walls of Thomism to explore the other more modern and contemporary philosophical trends, why was it that Filipino philosophy remained underdeveloped $(1999,7)$ ? In that same year, my deeper analysis goaded me to the insight that most probably those Filipino professors who breached the Thomistic prison walls retained the dogmatic ethos of such medieval school even as they rambled around the immense variety of other philosophical systems $(1999,10-$ 13). This means that even if those Filipino philosophy professors were no longer talking about Thomism, they tackled the other philosophies while unconsciously concerned about exactness and fearful of distorting such philosophies through applications, analyses, evaluations and other higher cognitive processes. Figure 1 shows how I holistically conceptualized philosophy in 1999 (1999, 11).

Using the said figure, I $(1999,11)$ pointed out that Filipino philosophy's way of philosophizing focused only on the answers element and disregarded the other elements and potentials of philosophy. A philosophy that emphasizes only one out 
of supposedly seven elements is a deformed philosophy. Hence, instead of dealing with living philosophies that could potentially catalyze the development of Filipino

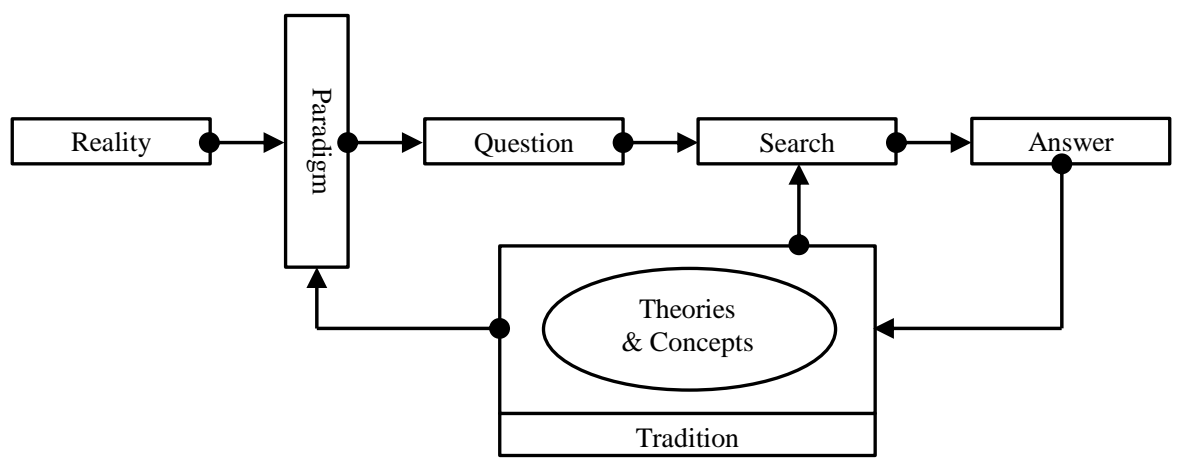

Figure 1: My 1999 Holistic Conceptualization of Philosophy

philosophy, those Filipino philosophy professors who were supposed to be freed from the hegemony of Thomism ended up telling tales about dead thoughts of dead people, forgetting in the process that philosophy is not mainly about talking about philosophy but more about using philosophy to address questions that matter to a given people in a given time.

The second historical problem concerning the underdevelopment of Filipino philosophy that was identified by Quito was the impact of the Marcos dictatorship on free and creative thinking. Writing a few years prior to the final crumbling of such dictatorial regime in 1986, Quito (1983, 54) asserted: "the present political dispensation inhibits the flowering of philosophical thought. History offers us several cases in which any form of political repression has suppressed freedom of thought."

In 1999, I missed the significance of this second historical problem mentioned by Quito. But in 2003 I already realized its profound impact on Filipino philosophy, not through Quito's 1983 book, but through my own reflections on the essays of Fernando Nakpil-Zialcita, entitled "Mga Anyo ng Pilosopiyang Pilipino" (1983), and Romualdo Abulad (1947-2019), entitled "Contemporary Filipino Philosophy" (1988). Such reflections, however, were undertaken with the recollections of my second and last face to face interaction with Quito during an open forum of the First Thomasian Philosophers' Reunion in 2000, where she talked about being harassed by some agents of the Marcos regime while preparing a book manuscript that contained some critical elements. I will elaborate on this profound realization in the succeeding section of this paper.

\section{Economic and Institutional Problems}

There were a number of economic and institutional problems that caused the underdevelopment of Filipino philosophy as identified by Quito: 1) low salaries of academic personnel; 2) inability of the teaching profession to attract the brightest 
students; 3) lack of research funds; 4) staggering teaching assignments; 5) absence of institutional expectation for research productivity on the part of philosophy professors; and 6) deficient faculty development program, in particular the lack of opportunity to earn graduate degrees abroad (1983, 49-51).

In 1999, I asked that even though salaries for academic personnel were already becoming more and more decent, a number of bright students were already attracted towards teaching career at some HEIs, some research funds were already up for grabs, teaching assignments were already eased in some of the leading Philippine HEIs, research productivity was already becoming a mantra in many Philippine HEIs, and faculty development programs were already set up, why was it that Filipino philosophy remained underdeveloped $(1999,8)$. In that same year, my deeper analysis made used of Michel Foucault's (1926-1984) notion of discursive formations to refer to the things seen as missing by Quito in 1983, but as emerging by me in 1999 (1999, 13-14). Such discursive formations when taken in isolation from each other would not amount into a coherent knowledge production. On the contrary these must interact together for a longer duration of time before Filipino philosophy can be tangibly produced. In 1999, I challenged the Filipino professors of philosophy to make do of the emergent discursive formations and work harder to make these discursive formations interact together to finally generate a stream of Filipino philosophizing $(1999,14)$.

\section{Linguistic Problems}

There were two linguistic problems that hindered the development of Filipino philosophy according to Quito. The first was about the Filipino philosophy teachers' lack of working knowledge on the leading languages used in philosophizing, such as French and German. Quito wrote: "professors who know no other language than English are greatly handicapped in philosophical research. They depend on translations which are most often mere interpretations" $(1983,49)$. The second was about the Filipino philosophy teachers' failure to exploit the Philippine national language. Quito $(1983,54)$ said: "Filipino thought is stifled by a foreign language such as English in which the average Filipino expresses himself."

In 1999, I $(1999,8)$ did not agree with Quito that our inability to deal with other European languages was enough to cripple the development of Filipino philosophy. I argued that we could initially rely on the robust Anglo-American translation machinery. Once we have identified our specific foreign philosophical specialization, then that could be the time for us to study and master specific foreign languages. In that same year, I also did not agree with Quito that our inability to use the Filipino language was enough to cripple the development of Filipino philosophy (1999, 8-9). I argued that there were many European philosophers who did not use their own

language to philosophize. In that same year, my deeper analysis made me state that if there is a real linguistic problem that hindered the development of Filipino philosophy it was our collective failure to use philosophy as a language to explore our inner and outer worlds $(1999,14-16)$. 


\section{Cultural Problem}

Quito noted that in the Philipppines philosophy has a negative connotation. She $(1983,9)$ asserted: "the term (pilosopo) alludes to a character called "Pilosopo Tasyo" (Tasyo, the Philosopher) who perorates endlessley in one of the novels of the Philippines' national hero, Jose Rizal (1861-1896).” In 1999, I disagreed with Quito that Pilosopo Tasyo is the cause of the Filipino's low regard for philosophy $(1999,9)$. I argued that Pilosopo Tasyo's placement in the margin of Philippine $19^{\text {th }}$ century society was actually a symptom of the fact that real and relevant philosophers had no place in such society. My point was that even before Rizal's creation of Pilosopo Tasyo Filipinos already had a low regard for philosophers $(1999,9)$.

In that same year my deeper analysis was aided by an essay on Filipino philosophy that was published in Ensayklopidya ng Pilosopiya that I thought was also written by Quito. That essay led me to argue it was the Filipino's culture of orality, based on the orality-textuality binary of the American literary and cultural theorist Walter Ong (19122003), that hindered our fuller appreciation of philosophy $(1999,17-20)$.

\section{Hope for Filipino Philosophy}

Quito made a distinction between philosophy in the strict sense of the word, or academic philosophy, and philosophy in the loose sense of the word, or folk philosophy or worldview $(1983,10)$. Whereas the philosophy in the strict sense hardly exists in the Philippines, philosophy in the loose sense is undeniably there $(1983,10)$. She $(1983,10)$ stressed: "this collective mind, this general attitude toward life, this concerted effort to acquire wisdom which is manifest on the popular or grassroots level constitutes the folk spirit (Volksgeist) of the Filipino and it should (or will) eventually emerge as a formalized philosophy on the academic level. This philosophy is, however, still in the process of formalization." In 1999, I (1999, 20-21) agreed with Quito's prognosis on Filipino philosophy. But I already noted that such is not enough to fully catalyze the development of Filipino philosophy. I (1999, 20-21) insisted that Filipino philosophy should not be afraid of borrowing foreign theories and concepts, as long as such borrowings are done reflectively and are applied as research paradigms and methodologies.

\section{CRITICAL REFLECTIONS ON MY READING AND RE-READING OF QUITO}

As mentioned in the introductory section of this paper, this second substantive section would be my present commentary on Quito's four cluster of causes and hope as well, as on my 1999 reflections on these same causes and hope.

\section{On the Historical Problems}

Concerning the first historical problem identified by Quito, I somewhat temper my 1999 critique where I pointed out that even though there were already a number of 
Filipino professors who breached the cognitive prison walls of Thomism to explore the other more modern and contemporary philosophical trends, those Filipino professors were still philosophizing under the specter of Thomism. We are overly concerned with exactness of our interpretations and avoiding distorting such newer philosophical trends through applications, analyses and evaluations and other higher cognitive processes.

During the times when Thomism was the overtly hegemonic philosophy, such system was taught to us in a dogmatic fashion that left no room for creativity and experimentation. Subtle warnings are relayed that deviations from the orthodox interpretations of Thomism can end with heresies and damnations. Hence, the predominant philosophical writing today among Filipino philosophy professors is the exposition of various philosophical systems, or the telling of tales about dead thoughts of dead people. In 2000, Florentino Hornedo came up with a dramatic term, "intellectual necrophilia," to describe this trend of philosophizing among Filipinos (Altez-Albela 2016, 66). Ruby Suazo, president of the Philosophical Association of Visayas and Mindanao, would corroborate these ideas but coming from his critical comparison of Filipino philosophy with Chinese and Japanese philosophies. He said: "I really feel that we are philosophizing the wrong way. I found that light from my reflection on the philosophizing of Confucius, Fukuzawa Yukichi and Nishi Amane. Their philosophizing. . . was really a product of their desire to find solution to the problem that pressed them that time" (Suazo 2019).

When we limit our philosophizing to the exposition of various philosophical systems, Filipino philosophy will be tied only to the levels of remembering and understanding, following the hierarchy of cognitive processes as conceptualized by Benjamin Bloom (Bloom, et al., 1956). However, if and when Filipino philosophy professors experiment by using these various philosophies as tools of examining and eventually solving problems that concerned us as a people, then we will be simultaneously remembering, understanding, and applying a given philosophical system, and even analyzing and evaluating aspects of our inner and outer worlds (Bloom, et al. 1956). This means that this bolder and alternative mode of philosophizing will not only allow us to move through different levels of cognitive processes in Bloom's hierarchy, but more so catalyze the further development of Filipino philosophy by collectively putting us just a notch below the goal of eventually creating a new and original philosophical discourse that is truly Filipino.

At present, the trend of moving out from the cognitive prison wall of Thomism continues. Kritike: An Online Journal of Philosophy, for example, the prime philosophical journal of the University of Santo Tomas, the supposedly ground zero of Philippine Thomism, surprisingly has only 5 articles $(1.98 \%)$ that are dealing with Thomism out of its 252 articles from 2008 to 2018. This is an auspicious sign, and should be followed up with some conscious efforts in remedying our structurally deformed way of doing philosophy. Since discourses are self-replicating, it is much easier for philosophy professors to pass down to their students, and their students' 
students, such structural deformity, than for a generation of philosophy professors to point out such deformity with consequent resolutions towards its remedy.

Concerning the second historical problem, in my 2003 article "Thought and Socio-Politics: An Account of the Late Twentieth Century Filipino Philosophy" I (2003) noted that although the Marcos regime stunted the development of Filipino philosophy as critical analysis, it did not have any effect on the blooming of Filipino philosophy as interpretation of Filipino worldview and identity. After all, the fascist agenda of Marcos of spinning an epic Filipino past and megalithic identity, as made manifest by his Tadhana project, is closely analogous with Filipino philosophy as interpretation of the Filipino worldview and identity. Although I agree with Quito that the Marcos regime did a great damage to Filipino philosophy, I just could not agree with her that it hindered its development.

\section{On the Economic and Institutional Problems}

I now find my 1999 recommendation on the economic and institutional problems inadequate and even unfair to Filipino philosophy professors. Merely challenging them to make do of the emergent discursive formations and to work harder to make such discursive formations interact together would probably elicit some positive responses from the most dedicated academics. But what we need for Filipino philosophy to further develop are not sporadic and scattered responses, but systemic and sustained responses. Hence, such discursive formations that have increased in magnitude and occurrence at present, need to be tied together not by individual efforts of the most dedicated Filipino philosophy professors but by stronger and more stable institutional efforts.

Decent salaries for academic personnel, the attraction of bright students towards the teaching career, the availability of research funds, the easing of teaching assignments, the expectation to continually do research, and the establishment of efficient faculty development programs can be effectively tied together in a functional research university. The robust research university will not only be a strong and stable institution to contextualize these discursive formations, but it also has an added feature which is the training of philosophy graduate students not just to teach philosophy but more so to actually philosophize. Whereas not all Philippine higher educational institutions should transition from teaching universities into research universities, having a handful real research universities is already enough to set the national standards of institutionally supported philosophizing, and of teaching graduate students to actually philosophize. The University of the Philippines and De La Salle University started their transformations into research universities in 2008 and 2011 respectively. But both have yet to attain the status of strong research universities.

If the German research university, the model of the modern research university, was invented by a philosopher, Wilhelm von Humboldt (1767-1835), more than two centuries ago, it would be dramatic if here in the Philippines the establishment of miniresearch universities will be spearheaded by philosophy departments and graduate schools. I think the Philosophy Department of the University of Santo Tomas is 
experimenting on putting up a system where thorough and sustained mentoring of their graduate students is pursued. The positive impact of this baby step towards dreaming for a strong research university will hopefully be felt in the coming years. I doubt if similar steps are even done in the philosophy departments of the two Philippine universities that are leading the transition into research universities.

\section{On the Linguistic Problems}

I stand by my 1999 critique on Quito's statement that our inability to deal with other European languages was enough to cripple the development of Filipino philosophy. I also stand by my 1999 deeper analysis that if ever there is a linguistic problem encountered by Filipino philosophy such problem is our failure to use philosophy as a language to explore and analyze our own inner and outer worlds. Such deeper analysis on the linguistic problem actually dovetailed with my deeper analysis on the first historical problem of Filipino philosophy that hindered us from treating inflowing philosophical systems as living philosophies that could potentially catalyze the further development of Filipino philosophy.

There are modifications, however, on my critique on Quito's statement that our inability to use the Filipino language was enough to cripple the development of Filipino philosophy. These modifications are brought about by my experimentation of using the Filipino language in teaching philosophy in 2000 in Mindoro, by my abrupt transfer from the Philosophy Department of San Beda College to the Filipino Department of De La Salle University in 2008, as well as by my reflection on my own use of the Filipino language in academic writing since 2009. The platform Academia.edu allowed me to monitor the language preferences of my online readers. The same platform also allowed me to take a look into the language preferences of the online readers of another Filipino philosophy professor who also write in both the Filipino and English languages, Napoleon Mabaquiao of De La Salle University. In as much as I wanted to expand the subjects of my hurried comparative analysis, I can only think of the two of us, at present, who extensively use both languages and who are actively utilizing the Academia.edu platform. Table 1 shows the data that I scoured from our Academia.edu pages on 15 May 2019.

The table demonstrates that our combined average view percentage per Filipino paper is $95.36 \%$, while our combined average view percentage per English paper is only $4.64 \%$. These mean that our combined average view percentage per Filipino paper is $90.72 \%$ higher than those of our English papers. The positive lesson that I gleaned from these figures is that there will be more Filipinos who will read our writings if these are written in the Filipino language; and the negative lesson is that we will end up with very few readers if we insist on writing for that universal but imaginary Anglophone audience.

Our failure to use the Filipino language might not actually cripple the development of Filipino philosophy, but there is so much to miss if we do not take 


\begin{tabular}{|c|c|c|c|}
\hline & $\begin{array}{l}\text { Demeterio's } \\
\text { Academia.edu } \\
\text { Page }\end{array}$ & $\begin{array}{l}\text { Mabaquiao's } \\
\text { Academia.edu } \\
\text { Page }\end{array}$ & $\begin{array}{l}\text { Combined } \\
\text { Academia.edu } \\
\text { Pages }\end{array}$ \\
\hline English Papers & 30 & 16 & 46 \\
\hline Filipino Papers & 22 & 9 & 31 \\
\hline $\begin{array}{l}\text { Total Views for } \\
\text { English Papers }\end{array}$ & 12,716 & 968 & 13,684 \\
\hline $\begin{array}{l}\text { Total Views for } \\
\text { Filipino Papers }\end{array}$ & 117,224 & 72,173 & 189,397 \\
\hline $\begin{array}{l}\text { Average Views per } \\
\text { English Paper }(\%)\end{array}$ & $\begin{array}{r}423.87 \\
(7.37 \%) \\
\end{array}$ & $\begin{array}{r}60.50 \\
(0.75 \%) \\
\end{array}$ & $\begin{array}{r}297.48 \\
(4.64 \%) \\
\end{array}$ \\
\hline $\begin{array}{l}\text { Average Views per } \\
\text { Filipino Paper }(\%)\end{array}$ & $\begin{array}{r}5,328.36 \\
(92.63 \%)\end{array}$ & $\begin{array}{r}8,019.22 \\
(99.25 \%)\end{array}$ & $\begin{array}{l}6,109.58 \\
(95.36 \%)\end{array}$ \\
\hline
\end{tabular}

Table 1: Comparison on the Average Views per Filipino and English Articles in Demeterio and Mabaquiao's Academia.edu Pages

advantage of the Filipino language in philosophizing. First, as shown by the table above, our philosophical writings will become more accessible to Filipinos if these are written in the Filipino language. This implies that if more and more Filipinos will be reading our philosophical writings, sooner or later they will realize the importance of philosophy. The language that almost unambiguously constructed "pilosopo" as a negative concept could be the same language that will restore the noble meaning of the said word. Second, if we philosophize using the Filipino language it will be easier for us to connect ourselves to our native world of concepts and thought systems. This will then catalyze the development of Filipino philosophy along the pathway of Quito's hope. Third, if we philosophize using the Filipino language we will be reminded constantly that we are philosophizing for the Filipinos. This will expel from our discourse the charming specter of the universal Anglophone audience, and make us realize that the pressure to be a world class philosopher is senseless if in our own Filipino world, we are irrelevant. Fourth, since we are philosophizing for the Filipinos our philosophy will be drawn closer to problems that bothering us as a people.

I am very aware that my fellow Cebuano-speaking philosophy professors are not comfortable with the idea of exploiting the Filipino language. In 1999, I too was uncomfortable, simply because I was not trained to use such language at the University of Santo Tomas or even at the University of the Philippines - Diliman. Until this present moment, I am still not confident in using the Filipino language, and I hire Filipino language editors for my Filipino texts. But the statistics from my Academia.edu page are telling me that my choice of using the Filipino language for some of my academic papers is on the right track. Andrew Gonzalez $(2000,7)$ once wrote that our mistake is that we framed the national language debate as a symbolic and political issue that is devoid of a sense of urgency. He $(2000,7)$ said that we should have framed it as a pragmatic and pedagogical issue that needs to be resolved 
in the soonest possible time. He meant that our people needs a common language that is much easier to master and use, and this need is something that is very urgent.

\section{On the Cultural Problem}

I stand by my 1999 statement that Pilosopo Tasyo could not be the cause the Filipino's low regard for philosophy. I based my argument then on internal analysis of Rizal's Noli Me Tangere. In 2005 I made a deeper study on the representation of philosophers and intellectuals in the two novels of Rizal, in an essay entitled "Thomism and Filipino Philosophy in the Novels of Jose Rizal" (2005). In that essay, I (2005) argued that in order to maintain the realistic tone of his novels Rizal had no choice but to give the central intellectual sphere to the Dominican Thomists, and Tasyo had to be relegated to the margins, just as the other four intellectuals, Crisostomo Ibarra, Elias, Simoun, and Padre Florentino, had to be pushed away from that central intellectual sphere.

At present I was able to scour out a textual proof that antedated Rizal's birth by more than thirty years, and the publication of Noli Me Tangere by almost sixty years, and this is from Henry Piddington's 1828 book Remarks on the Philippine Islands, and on their Capital, Manila: 1819 to 1822 (1928). In a footnote, Piddington (1928, 145) wrote an advice to other westerners who might want to visit the Philippines, telling them just to introduce themselves as "old Christians," and never as "philosophers" because such term is "an epithet of reproach." Hence, even before Tasyo was created by Rizal, the word "pilosopo" already had an unpleasant connotation in the country.

But what caused this low regard for philosophers? Rizal's first novel offers us a clue. When Tasyo, the wise man who is reputed to be a fool, compared himself with the gobernadorcillo, the mediocre man who is reputed to be a wise person, Rizal made the old man rant: "the curate calls me 'philosopher' as a nickname and gives to understand that I am a charlatan who is making a show of what I learned in the higher schools" $(1912,192)$. A few pages prior to this rant, Rizal made Tasyo explain to the amazed Crisostomo Ibarra that he is writing in hieroglyphs for fear that his bold and radical discourses will only be burned $(1912,189)$. There is a very subtle suggestion from these lines that the denigration of the pilosopo is an effect of the colonial order as perpetuated by the friars and the Spanish civil officials based on their distaste for inquisitive and critical-minded Indios. Thus, the filosofos, herejes, and filibusteros were clustered together as undesirables in the context of an actually fragile colonial society. Such hegemonic distaste could have been easily passed down and internalized by the colonial subjects themselves, just as the curate's construction of pilosopo as a nickname of Tasyo was readily accepted by the general population of Noli Me Tangere's fictional world.

In 1999, my deeper analysis on the cultural problem of Filipino philosophy was aided by an essay on Filipino philosophy that was published in the Ensayklopidya ng Pilosopiya. I discovered in 2013, while researching for an article entitled "Quito, 
Ceniza, Timbreza, Gripaldo: DLSU Professors' Contributions to Filipino Philosophy," that the essay that I used in 1999 actually belonged to Florentino Timbreza and not to Quito (Timbreza 1993). But such mistake would not invalidate my stand that the Filipino's culture of orality is a deeper cultural problem that hindered the development of Filipino philosophy. Even if the pilosopo was not denigrated by the colonial order, philosophy's highly textual nature would not easily dovetail with the Filipinos' oral predisposition.

But just like the denigrated pilosopo, this culture of orality can also be a product of our colonial experiences. First, there was this unwillingness on the part of the Spanish colonizers to share their language and texts with the Indios. Second, we had an inferior Spanish colonial educational system. Third, there was this stringent censorship implemented by the Spanish authories. Thus, even if there were more Filipinos who could read, there would hardly be anything worthwhile to read. Even the Spanish bible was a forbidden reading material for the Indios (Laubach 1925, 150169). Fourth, when we shifted to the widespread use of the English language we were flooded with materials that the average Filipino could still hardly understand.

\section{Synthesis on the Causes of Underdevelopment of Filipino Philosophy}

The historical, economic and institutional, linguistic, and cultural problems that hindered the development of Filipino philosophy are actually not isolated problems but are interconnected and interlocking factors. They are more like an assemblage of the French philosopher and cultural critic Gilles Deleuze (1925-1995) and the French psychotherapist and intellectual Pierre-Felix Guattari (1930-1992), where such factors interact with each other. This paper has already bundled together Quito's economic and institutional problems as effects of our failure to have our own strong universities, even if the idea of the research university was invented more than 200 two hundred years ago. This paper, furthermore, will interconnect the four problems mentioned by Quito by mooring them back to our colonial experiences. Figure 2 represents this paper's discovery of the interrelationships among Quito's historical, economic and institutional, linguistic, and cultural hindrances.

Our Spanish colonial experience made Thomism the dominant philosophy for so many years, such experience failed to provide us with research universities, and such experience discouraged us from cultivating an intellectual culture, and reinforced our culture of orality. Our American colonial experience also failed to provide us with research universities, its lasting impact make us unwilling to fully use our own national language, and the English texts that such experience spawned are largely unreadable to the ordinary Filipinos further reinforced our culture of orality. Even Martial Law is an aberration of the American experiment of transplanting democracy into a society where economic and cultural capitals were so unevenly distributed, and the Dictator Marcos enjoyed the support from the American government for so long.

The predominance of Thomism left us with a philosophy that we do not use as a tool for analysis. This deformed philosophy is reinforced by our philosophy professors' languorous stance to philosophical research, as a result of our failure to have strong research universities to set the standards of research excellence. This deformed philosophy 


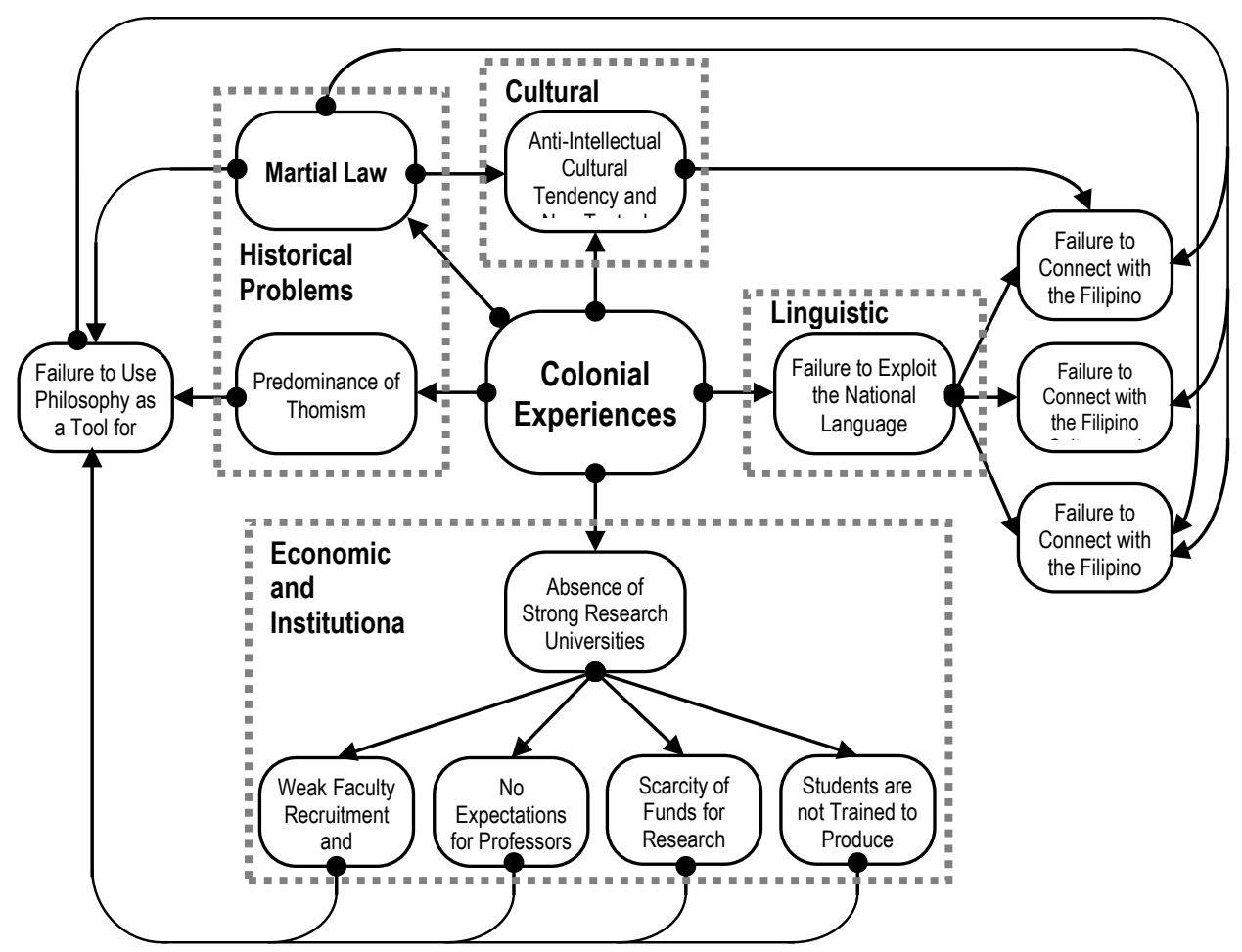

Figure 2: Colonialism and the Interconnections among Quito's Historical, Economic and Institutional, Linguistic, and Cultural Problems that Hindered the Development of Filipino Philosophy

was also reinforced by the oppressive atmosphere of Martial Law.

Filipino philosophy's failure to fully exploit the national language and its failure to use philosophy as a tool for analysis made it fail to connect with the Filipino people, with the Filipino culture and tradition, and with the Filipino world. Our anti-intellectual and oral culture hindered Filipino philosophy's connection with the Filipino people. As already mentioned, the absence of a strong research university bundled together Quito's economic and institutional problems.

\section{On the Hope for Filipino Philosophy}

In 1999, I agreed with Quito's hope that Filipino philosophy will be catalyzed to develop further by the Filipino folk spirit. But in that same year, I already voiced out my dissatisfaction for such single-tracked vision. I argued in that year that Filipino 
philosophy should not be afraid of borrowing foreign theories and concepts, as long as such borrowings are done reflectively and are applied as research paradigms and methodologies.

In 2014, I came up with an article "Assessing the Developmental Potentials of some Twelve Discourses of Filipino Philosophy" where I conceptualized Filipino philosophy as multi-tracked and where I analyzed the promises of such tracks. These twelve overlapping tracks that I synthesized in 2013 from the reflective writings of Nakpil-Zialcita, Timbreza, Quito, Abulad, Mabaquiao, Rolando Gripaldo (19472017), and Alfredo Co, are: 1) exposition of foreign systems, 2) application of logical analysis, 3) application of phenomenology and hermeneutics, 4) appropriation of foreign theories, 5) revisionist writing, 6) academic critical analysis, 7) interpretation of the Filipino worldview and identity, 8) research on Filipino ethics and values, 9) appropriation of folk spirit, 10) study on the presuppositions and implications of the Filipino worldview and identity, 11) study of the Filipino philosophical luminaries, and 12) philosophizing using the Filipino language (2014a). Quito's sole track corresponds to the ninth one.

Using the criteria of the tracks' Filipinoness, cognitive level, emotional energy, impact, and sustainability, the following tracks were identified as having high developmental potentials: 1) appropriation of foreign theories, 2) academic critical analysis, 3) research on Filipino ethics and values, 4) appropriation of the folk spirit, and 5) study on the presuppositions and implications of the Filipino worldview (2014a). Using the same criteria, the following tracks were identified as having medium developmental potentials: 1) application of logical analysis, 2) application of phenomenology and hermeneutics, 3) revisionist writing, 4) interpretation of the Filipino worldview, and 5) study on the Filipino philosophical luminaries (2014a). Finally, with the same criteria, the track of Filipino philosophy as exposition of foreign systems was identified as having low developmental potential (2014a). The track of Filipino philosophy as philosophizing using the Filipino language, since its actual contents can actually cut across all the preceding eleven tracks, is something that cannot be analyzed by the content-dependent criteria that I used in 2014.

At present, I would stress that the further development of Filipino philosophy should not rely only on the track on the appropriation of the folk spirit, but on all of the other tracks, special the ones with high developmental potentials. But this paper's fresh insight that the historical, economic and institutional, linguistic, and cultural hindrances are actually moored on our colonial experiences, would give us a warning that developing Filipino philosophy is not as easy as thinking along any of these twelve tracks. While we cannot go on blaming our Spanish and American colonizers, we should also not forget that colonization stamped long lasting marks on our social structures - such as our lack of strong research universities, on our collective consciousness - such as our low regard for the pilosopo as well as our culture of orality, and or our practices - such as our deformed way of philosophizing and refusal to exploit the Filipino language. Hence, we should be conscious that in the Philippines to philosophize is to think against the powerful stream of over four hundred years of colonization. Our Spanish and American colonial experiences, and our experience of the repressive Marcos Regime are facts that are given, and we cannot do undo them. 
But we can do something, in fact a lot of things, on their impact on our social structures, collective consciousness, and practices.

\section{CONCLUSION}

Quito's analysis on the underdevelopment and hope for development of Filipino philosophy, was one of the first and sustained studies undertaken on the said matters. Much of what she wrote remains relevant and true. But after almost four decades since the publication of her critique, such needs to be re-read and re-contextualized to the changing times. Table 2 summarizes Quito's points as well as my 1999 and present commentaries.

\begin{tabular}{|c|c|c|c|}
\hline \multicolumn{2}{|c|}{$\begin{array}{l}\text { Quito's Diagnosis and } \\
\text { Hope }\end{array}$} & $\begin{array}{l}\text { Demeterio’s } \\
1999 \\
\text { Commentary }\end{array}$ & $\begin{array}{l}\text { Demeterio's } 2019 \\
\text { Commentary }\end{array}$ \\
\hline \multirow{2}{*}{$\begin{array}{l}\text { Historical } \\
\text { Problems }\end{array}$} & $\begin{array}{l}\text { Predominance } \\
\text { of Thomism }\end{array}$ & $\begin{array}{l}\text { Thomism's } \\
\text { deformed the } \\
\text { way Filipinos } \\
\text { deal with } \\
\text { philosophy } \\
\text { We do not use } \\
\text { philosophy as a } \\
\text { tool of analyzing } \\
\text { our Inner and } \\
\text { outer worlds }\end{array}$ & $\begin{array}{l}\text { Exodus from the } \\
\text { hegemony of Thomism } \\
\text { continues } \\
\text { There is a need to } \\
\text { systematically point out } \\
\text { the deformed way on } \\
\text { how Filipinos deal with } \\
\text { philosophy and make } \\
\text { lasting resolutions } \\
\text { towards its remedy }\end{array}$ \\
\hline & $\begin{array}{l}\text { Intellectual } \\
\text { repression of } \\
\text { Martial Law }\end{array}$ & & $\begin{array}{l}\text { Martial Law } \\
\text { cultivated/tolerated the } \\
\text { development of } \\
\text { Filipino philosophy as } \\
\text { the interpretation of the } \\
\text { Filipino worldview } \\
\text { Martial Law curtailed } \\
\text { the development of } \\
\text { Filipino philosophy as } \\
\text { academic critical } \\
\text { philosophy }\end{array}$ \\
\hline \multirow{2}{*}{$\begin{array}{l}\text { Institutional } \\
\text { Problems }\end{array}$} & $\begin{array}{l}\text { Low salary of } \\
\text { academic } \\
\text { personnel }\end{array}$ & \multirow{2}{*}{$\begin{array}{l}\text { Things have } \\
\text { improved to a } \\
\text { certain extend in } \\
\text { 1999, but such } \\
\text { improvements }\end{array}$} & \multirow{2}{*}{$\begin{array}{l}\text { Things have further } \\
\text { improved in } 2019 \\
\text { Such improvements } \\
\text { need to be tied together }\end{array}$} \\
\hline & $\begin{array}{l}\text { Inability to } \\
\text { recruit the }\end{array}$ & & \\
\hline
\end{tabular}




\begin{tabular}{|c|c|c|c|}
\hline & $\begin{array}{l}\text { brightest } \\
\text { students into } \\
\text { the academe }\end{array}$ & \multirow{5}{*}{$\begin{array}{l}\text { did not interact } \\
\text { with each other } \\
\text { to create a } \\
\text { unified } \\
\text { discursive } \\
\text { formation }\end{array}$} & \multirow{5}{*}{$\begin{array}{l}\text { in a stable context such } \\
\text { as a strong research } \\
\text { university } \\
\text { Such desired institution } \\
\text { will set the standards of } \\
\text { excellence in research } \\
\text { and philosophizing }\end{array}$} \\
\hline & $\begin{array}{l}\text { Lack of } \\
\text { research funds }\end{array}$ & & \\
\hline & $\begin{array}{l}\text { Staggering } \\
\text { teaching } \\
\text { assignments }\end{array}$ & & \\
\hline & $\begin{array}{l}\text { No institutional } \\
\text { expectation for } \\
\text { professors to } \\
\text { undertake } \\
\text { research }\end{array}$ & & \\
\hline & $\begin{array}{l}\text { Deficient } \\
\text { faculty } \\
\text { development } \\
\text { program }\end{array}$ & & \\
\hline \multirow[b]{3}{*}{$\begin{array}{l}\text { Linguistic } \\
\text { Problems }\end{array}$} & $\begin{array}{l}\text { Inability to } \\
\text { deal with the } \\
\text { major } \\
\text { European }\end{array}$ & \multirow{2}{*}{\multicolumn{2}{|c|}{$\begin{array}{l}\text { Filipino philosophy professors' inability to } \\
\text { deal with the major foreign languages is not } \\
\text { enough to cripple the development of } \\
\text { Filipino philosophy } \\
\text { Filipino philosophy professors did not use } \\
\text { philosophy as a language to talk about the } \\
\text { Filipinos' inner and outer worlds }\end{array}$}} \\
\hline & $\begin{array}{l}\text { languages, } \\
\text { such as French } \\
\text { and German }\end{array}$ & & \\
\hline & $\begin{array}{l}\text { Failure to } \\
\text { utilize the } \\
\text { Philippine } \\
\text { national } \\
\text { language }\end{array}$ & $\begin{array}{l}\text { Filipino } \\
\text { philosophy } \\
\text { professors' failure } \\
\text { to utilize the } \\
\text { Filipino language } \\
\text { is not enough to } \\
\text { cripple to } \\
\text { development of } \\
\text { Filipino } \\
\text { philosophy }\end{array}$ & $\begin{array}{l}\text { Filipino language will } \\
\text { connect Filipino } \\
\text { philosophy with the } \\
\text { Filipino people, } \\
\text { culture, tradition and } \\
\text { world }\end{array}$ \\
\hline $\begin{array}{l}\text { Cultural } \\
\text { Problem }\end{array}$ & $\begin{array}{l}\text { Low regard for } \\
\text { the pilosopo }\end{array}$ & $\begin{array}{l}\text { The culture of } \\
\text { orality is a deeper } \\
\text { problem }\end{array}$ & $\begin{array}{l}\text { The low regard for the } \\
\text { pilosopo and the } \\
\text { culture of orality are } \\
\text { remnants of our } \\
\text { colonial experiences } \\
\text { These baggage hinder } \\
\text { the connection of } \\
\text { Filipino philosophy } \\
\end{array}$ \\
\hline
\end{tabular}




\begin{tabular}{|c|c|c|c|}
\hline & & & $\begin{array}{l}\text { with the Filipino } \\
\text { people }\end{array}$ \\
\hline $\begin{array}{l}\text { Hope for } \\
\text { Filipino } \\
\text { Philosophy }\end{array}$ & $\begin{array}{l}\text { Development } \\
\text { of Filipino } \\
\text { philosophy } \\
\text { will be } \\
\text { catalyzed by } \\
\text { Filipino folk } \\
\text { spirit }\end{array}$ & $\begin{array}{l}\text { The catalyzing } \\
\text { power of the } \\
\text { Filipino folk spirit } \\
\text { should be assisted } \\
\text { with pragmatic } \\
\text { borrowings of } \\
\text { western theories } \\
\text { and concepts }\end{array}$ & $\begin{array}{l}\text { The development of } \\
\text { Filipino philosophy } \\
\text { should move through } \\
\text { multiple tracks } \\
\text { Filipino philosophy } \\
\text { professors should be } \\
\text { aware that to } \\
\text { philosophize is to } \\
\text { work against the } \\
\text { structural, mental and } \\
\text { praxiological remnants } \\
\text { of colonization }\end{array}$ \\
\hline
\end{tabular}

Table 2: Summary of Quito's Points, and of Demeterio's 1999 and 2019 Commentaries

As long as Filipino philosophy professors are aware about the problems that hindered the development of Filipino philosophy, our diagnoses are actually full of optimism. The hindrances that we catalogued are not indestructible fortresses. Quito was not able to see and talk about so much developments in Filipino philosophy in 1983 , and maybe even for the greater part of the beginning of the $21^{\text {st }}$ century, as she opted to pursue a reclusive life until her death in 2017. But I saw a lot of positive things happening for Filipino philosophy since 1999. There are many younger Filipino professors and instructors of philosophy now who are bravely philosophizing and publishing, maybe not through Quito's favored track, but certainly through many other tracks, including the ones that I might missed to list in 2013. Thus, my heart is full of hope for Filipino philosophy.

\section{REFERENCES}

Abulad, Romualdo E. 1988. Contemporary Filipino philosophy. Karunungan/Sophia 5. Altez-Albela, Fleurdeliz R. 2016. Phenomenologizing Filipino organic thought: Florentino H. Hornedo's philosophical anthropology. Kritike: An Online Journal of Philosophy 10 (2).

Bloom, Benjamin, et al. 1959. Taxonomy of educational objectives: The classification of educational goals. New York: Longmans.

Demeterio, Feorillo A. 1999. Re-reading Emerita Quito's thoughts concerning the underdevelopment of Filipino philosophy. Scientia: The Research Journal of the College of Arts \& Sciences, San Beda College. 
Demeterio, Feorillo A. 2003. Thought and socio-politics: An account of the late twentieth century Filipino philosophy. Hingowa: The Holy Rosary Seminary Journal. 8 (2).

Demeterio, Feorillo A. 2005. Thomism and Filipino philosophy in the novels of Jose Rizal. Scientia: The Research Journal of the College of Arts \& Sciences, San Beda College.

Demeterio, Feorillo A. 2013. Status of and directions for Filipino philosophy in Zialcita, Timbreza, Quito, Abulad, Mabaquiao, Gripaldo, and Co. Philosophia: International Journal of Philosophy. 14 (2).

Demeterio, Feorillo A. 2014a. Assessing the developmental potentials of some twelve discourses of Filipino philosophy." Philippiniana Sacra. 69 (147).

Demeterio, Feorillo A. 2014b. Quito, Ceniza, Timbreza, Gripaldo: DLSU professors' contributions to Filipino philosophy. Philosophia: International Journal of Philosophy. 15 (2).

Foucault, Michel. 1980. Prison talk. Colin Gordon, Ed. Power/knowledge: Selected interview and other writings 1972-1977. London: Harvester Wheatsheaf.

Gonzalez, Andrew. 2000. The politics of language: Language, ethnicity, and nationstate in the Philippines. Asia-Pacific Social Science Review. 1 (2).

Gronbeck, Bruce E. 1991. "Rhetorical studies tradition and Walter J. Ong: Oralliteracy theories of mediation, culture, and consciousness. Edited by Bruce Gronbeck, Thomas Farell, \& Paul Soukups. Media consciousness, and culture. London: Sage Publications.

Laubach, Frank Charles. 1925. The people of the Philippines: Their religious progress and preparation for spiritual leadership in the Far East. New York: George $\mathrm{H}$. Doran Company.

Nakpil-Zialcita, Fernando. 1983. Mga anyo ng pilosopiyang Pilipino. Mga babasahin sa pilosopiya: Epistemolohiya, lohika, wika at pilosopiyang Pilipino. Edited by Virgilio Enriquez. Manila: Philippine Psychology Research and Training House.

Piddington, Henry. 1828 Remarks on the Philippine Islands, and on their capital, Manila: 1819 to 1822. The Philippine Islands 1493-1898. Edited by Emma Helen Blair \& James Alexander Robertson. Cleveland, Ohio: the Arthur H. Clark Company. Vol. 1, No. 51.

Quito, Emerita S. 1983. The state of philosophy in the Philippines. Manila: De La Salle University Press.

Rizal, Jose. 1912. Noli me tangere. Translated by Charles Derbyshire. Manila: Philippine Education Company.

Suazo, Ruby. 2019. Personal electronic correspondence.

Timbreza, Florentino T. 1993. Pilosopiyang Filipino. In Ensayklopidiya ng Pilosopiya. Edited by Emerita Quito, et al. Manila: De La Salle University Press.

Submitted: 22 June 2019; revised: 12 May 2020 